\title{
Adoption of People's Game as a Modification Technique in KIPAS Model Counseling
}

\author{
Andi Mappiare A. T. \\ Guidance and Counseling \\ Universitas Negeri Malang, Indonesia \\ andi.mappiare.fip@um.ac.id \\ Nur Hidayah \\ Guidance and Counseling \\ Universitas Negeri Malang, Indonesia \\ nur.hidayah.fip@um.ac.id
}

\author{
Muslihati \\ Guidance and Counseling \\ Universitas Negeri Malang, Indonesia \\ muslihati.fip@um.ac.id \\ Lutfi Fauzan \\ Guidance and Counseling \\ Universitas Negeri Malang, Indonesia \\ lutfialfauzan@gmail.com
}

\begin{abstract}
The main concern for KIPAS model counseling-Intensive and Progressive Counseling that is Adaptive to Structure - is that counseling needs to have modification techniques that are appropriate to the culture of the counselor and counseling. Only then can counseling be expected to be more effective. The technique that is culturally appropriate can be reconstructed from the strategy of cultural heritage of various ethnicities in Indonesia. When folk games and local practices are reconstructed into counseling techniques, counseling performs its function perfectly as a "forum for cultural encounters". This research has mapped the names of folk games and local practices with their respective designations for the modification of the topics of KIPASCharacter, Identity, Job/career, Academic/learning, and Social.
\end{abstract}

Keywords: counseling culture, modification techniques, kipas, intensive and progressive counseling adaptive to structures, guidance and counseling

\section{INTRODUCTION}

Characteristics in the context of the counselor's duties and surrounding culture, the use of infrastructure for counseling needs as well as "sociopolitical dynamics" (Sumari and Jalal, 2008) are necessary to be managed so that they can support in the construction of counseling with cultural content or content (Mappiare, Ibrahim, and Sudjiono, 2009).

Second, culture in the "Content System / Content" (Content System) counseling. Subjective culture which consists of value systems, religious norms, community norms, local wisdom, and indigenous customs becomes the content or content of counseling. A number of studies have been carried out regarding the subject's culture as guidance content in general and culture-based counseling in particular (Mappiare, 2010; 2015; Mappiare, Fachrurrazy, and Sudjiono, 2010; 2011; 2012; 2012; Mappiare, Fachrurrazy, and Faridati-Zen, 2014; Riswanto, Mappiare, and Irtaji, 2017; Silondae, 2013).

Third, culture in "Delivary System" (Delivary System) counseling. Counseling "transport systems" that are expected to be suitable for the community of actors and subjects served are those constructed or developed from the local objective culture. This can be in the form of various types of folk games that contain local wisdom that is modified, constructed or developed into counseling media so that it becomes a modification counseling technique (Hendratno, 2016). Quite a large opportunity for the application of various types of traditional games, such as the crank, sodor cart, and dakon in guidance at an early age (Widiasari, Susiati, and Saputra, 2017). Quite a number of recent studies have successfully tested the usefulness of a number of practices containing local culture and folk games to be used as a modification technique for counseling (Asfarina, 2013; Setyaputri, Ramli, and Mappiare, 2015).

Based on the above background the following research issues are raised: What local practices and / or folk games that can be adopted for the inheritance of character, identity, work culture, learning / academic culture, and ideal social skills that are expected to thrive on students?

\section{METHOD}

This research was conducted with qualitative methods of descriptive / interpretive type with focused ethnographic variants. There are three variants of ethnographic research: 'full-scale' ethnography, focused critical ethnography, and short ethnography and interviews. The chosen variant is 'wide-scale' ethnography (Alvesson and Skoldberg, 2000) which is carried out in discovering what folk games or local practices are likely to be adopted as a technique of modification in the counseling and how the specifications are intended.

The study was conducted on several Tidung ethnic community groups in the Tarakan city of Borneo, North Kalimantan, Mandar city communities in West Sulawesi, Malay communities especially in Bengkulu city, Madurese in Bangkalan and Sumenep, Samin communities in Blora, Central Java, and Kudus city communities in Central Java. The research site is determined based on the unique characteristics of the community: (1) still actively implementing their unique value system in everyday life; (2) still practiced a method or strategy of cultural inheritance that is unique in everyday life, or at least there is a text that can describe it clearly; and (3) there are trusted and approachable 
informants who can provide information on the cultural values needed.

Data collection techniques operated in this study were: First, observations were made on the actions and practices of the local subjects of the study, including folk games both conducted by adults and children. The aim is to record action and symbolic data in which values are held in high esteem by the local community. The interviews that are operated primarily are deep interviews. Second, in-depth interviews are conducted mainly to collect verbal data, namely verbalization or expressions of attitudes, feelings, community perceptions about how the strategy of inheriting local values. Third, the dialogue technique that is operated is the recording of information that appears in the natural and spontaneous dialogue of the subject under study, for example in a game of charity or local practice. Fourth, examination of documents and texts will be carried out on the texts of traditional records, messages of traditional elders, messages of parents who have been written, as well as texts in the form of folk songs, pantun, seloka, gurindam which can contain a value system culture and / or expectations of culturebased behavior that is expected to be passed down from the previous generation to the next generation. Data collection is also complemented by focus group discussions that will be carried out by field researchers in accordance with the particular characteristics of each field.

Data analysis is carried out first by identifying the names of local practices and / or folk games that are potentially reconstructed into modification techniques in counseling. Next is the representation of names and forms of local practices and / or folk games that have been adopted (along with their designation and specifications) for the inheritance of character, identity, work culture, learning / academic culture, and ideal social skills that are expected to grow and develop in students.

\section{RESULT AND DISCUSSION}

Descriptions of folk games and local practices and their specific provisions are as follows: (a) Character development can be done through folk games like "SlukuSluku", "Cublak-Cublak Suweng", "Dhakon", "Jirak / angkring", and "oglak-aglik"; (b) For affirmation of identity through the local practice of "Speech" or "Pappasang" in the form of poetry or poetry, through forums of poetry, poetry, cultural motto or discussion; (c) To brighten up the work culture through discussion forums, selfies, discussion forums or "Tarnish houses", "Freeze"; as well as "Market," and "Targeting," "Strain"; (d) For the brightness of academic culture / learning through "Dancing", "Starring", "Dhakon"; (e) For social skills planting can be done through "Fortress" or "Catchup". "Wheelchair", "Scooter", "Screw", "Tank", and "Tank-click".

Folk play and designation especially in the personal development of this research can be juxtaposed with various previous research findings. In general, the latest research has determined that traditional games have a very positive impact on children's development. First, traditional games tend to use tools and facilities that are available naturally in the environment so the effect is natural. Second, involving a relatively large number of players so that it is more efficient. Third, it has noble values and certain moral messages (Simorangkir, 2014). Group guidance with traditional games is to increase social interaction of elementary school level students (Yani, 2016). Interventions using traditional games can reduce excessive smartphone use, as well as revive local cultures that have positive values (Liza and Rusandi, 2017). Play therapy based on local wisdom is one of the innovative counseling techniques that needs to be designed by counselors specially to help early childhoods overcome their problems (Widiasari, Susiati, and Saputra, 2017). Traditional games and modern games have character values on cognitive, social, emotional and identity aspects. Traditional games tend to contain social character values, whereas modern games tend to contain individual character values (Irman, 2017).

If you see the designation, traditional games can be described more specifically and compared with the results of previous studies.

First, character development can be done through folk games in the form of "Sluku Bathok", "Cublak-cublak Suweng", "Dhakon", "Jirak / angkring", and "Dhingklik oglak-aglik". In other studies it was found that the cultivation of moral values and good character formation can be done by guidance and counseling teachers through local practices such as logos or symbols, such as the names of characters in puppets, batik art, and fruit / food symbols in kenduren (Effendi, 2017). Character enhancement can also be done through the game of congklak or dhakon (Lacksana, 2017). The formation of the character of students, especially students who have faith, piety and noble character, can be done through life skills education based on Islamic cultural values (Mawadi, 2012). Fostering character through selfunderstanding, humility and trustworthiness, can be done through the adoption of values in the local practice of "karia" rituals for young ethnic Muna girls in Southeast Sulawesi (Suriata, 2015). Culture and national character education can be embedded and developed in an integrated manner with educational activities in schools (Hakim, 2015).

Secondly, in this study a description was obtained that for the affirmation of identity through "Pitutur" or "Pappasang" in the form of poems or rhymes, through reciprocity rhymes, rhyming forums, discussion of cultural motto or discussion. In another study it was found that the game of congklak (dakon) was proven to foster national identity (Lacksana, 2017). Cultivation of selfrecognition and understanding of gender roles can also be done through the adoption of values in local practices of "karia" rituals for young Muna girls of Southeast Sulawesi (Suriata, 2015).

Third, for the brightness of work culture through deliberation forums, gatherings, discussion discussions or "Tudang sipulung", "Bek-rembek"; and "Market", and "Menaranan", "Stilts". In other studies, it was found that student career maturity can be shaped through traditional game techniques developed in group guidance (Leksana, 2017). Work values, such as skills and hard work, can be developed through the Banjarese Balogo game in South Kalimantan (Sugianto, 2017). 
Fourth, from this study found a description that for the brightness of academic / learning culture can be done through the game "Menaranan", "Stilts", "Dhakon". Other studies have found that to increase student creativity as a part of academic modality can be done through congklak or dakon games (Lacksana, 2017). Academic development or learning, especially self-actualization, can be carried out through the adoption of values in the local practice of "karia" rituals for young Muna girls of Southeast Sulawesi (Suriata, 2015).

Fifth, the results of this study obtained a description that for inculcation of social skills can be done through "Bentengan" or "Catch Lokam". "Gobak Sodor", "Menaranan", "Stilts", "Jirak / angkring", and "Dhingklik oglak-aglik". In another study it was found that the traditional game of Bugis-Makassar as a medium for guidance and counseling turned out to have the use, accuracy, feasibility and relevance to improve students' social skills (Kasim, 2017). Social values such as cooperation and sportsmanship can be developed through the Banjarese Balogo game in South Kalimantan (Sugianto, 2017). Preservation / cultural inheritance in the form of social interaction can be done with congklak or dakon games (Lacksana, 2017). To train children's social interactions, learn cooperation, be creative, train emotions, traditional games can be used in play therapy, such as dakon, crank, and sodor cart (Widiasari, Susiati, and Saputra, 2017).

\section{CONCLUSION}

There are five important conclusions about local practices and / or folk games that can be adopted in the KIPAS Model Counseling. The conclusions referred to are: First, for character development can be done through folk games in the form of "Sluku Bathok", "Cublak-cublak Suweng", "Dhakon", "Jirak / angkring", and "Dhingklik oglak-aglik". Second, for the affirmation of identity through "Pitutur" or "Pappasang" in the form of poems or rhymes, through reciprocated rhymes, rhyming forums, discussion of cultural motto or discussion. Third, for job / career brightness through deliberation forums, gatherings, discussion discussions or "Tudang sipulung", "Bekrembek"; and "Market", and "Menaranan", "Stilts". Fourth, for the brightness of academic / learning culture through "Menaranan", "Stilts", "Dhakon". Fifth, for the cultivation of social skills can be done through "Bentengan" or "Catch Lokam". "Gobak Sodor", "Menaranan", "Stilts", "Jirak / angkring", and "Dhingklik oglak-aglik".

The suggestions that should be offered from the results of this study are: to the teachers of guidance and counseling or education counselors are expected to explore the application of various folk games or local practices for internalization with the main function as cultural immunization to counter global influences or cultural injection as a healthier for various problems faced by students.

\section{REFERENCES}

[1] Alvesson, M., dan Skolberg, K. 2000. Reflexive Methodology: New Vistas for Qualitative Research. London: Sage Publications, Inc.
[2] Asfarina, L. M. A. 2013. Fleksibelitas Ekspresi Status Ego sebagai Fungsi dari Teknik Cangkrukan dan Drama Segitiga Karpman. Skripsi tidak dipublikasikan. Malang: Jurusan Psikologi Pendidikan dan Bimbingan, FIP Universitas Negeri Malang.

[3] Astawa, I.M.O. 2017. Bimbingan Belajar dan Karir Berbasis Kearifan Lokal dan Nilai Keluarga. Purwadita, 1(1): 77-63.

[4] Effendi, K. 2017. Logo atau Lambang Merupakan Bentuk Nilai Moral Isi Bimbingan dan Konseling. Prosiding Seminar Nasional Peran Bimbingan dan Konseling dalam Penguatan Pendidikan Karakter Universitas Ahmad Dahlan, 309-319.

[5] Hakim, D. 2015. Implementasi Pendidikan Budaya dan Karakter Bangsa dalam Kurikulum Tingkat Satuan Pendidikan (KTSP) di Sekolah. Religi: Jurnal Studi Islam, 6(2): 145-168.

[6] Irman, 2017. Nilai-Nilai Karakter pada Anak dalam Permainan Tradisional dan Moderen. Konseli: Jurnal Bimbingan dan Konseling, 2(4): 89-96.

[7] Kasim, S. N. O. 2017. Pengembangan panduan permainan tradisional bugis-makassar dalam meningkatkan keterampilan sosial Siswa. Jurnal Psikologi Pendidikan \& Konseling, 3(1): 45-52.

[8] Lacksana, I. 2017. Kearifan Lokal Permainan Congklak sebagai Penguatan Karakter Peserta Didik Melalui Layanan Bimbingan Konseling di Sekolah. Satya Widya, 33(2): 109 116.

[9] Leksana, D. M. 2017. Bimbingan Kelompok dengan Teknik Permainan Tradisional untuk Meningkatkan Penyesuaian Sosial. JCE, 1(1): 14-20.

[10] Liza, L. O, dan Rusandi, M. A. 2017. Konseling Kelompok dengan Permainan Tradisional Melayu untuk Megurangi Penggunaan Smartphone yang Berlebihan pada Anak. Proceeding International Seminar on Counseling, Malindo5: 224-230.

[11] MacCluskie, K. 2010. Aquiring Counseling Skills: Integrating Theory, Multiculturalism, and Self-Awareness. New Jersey: Pearson Education Inc.

[12] Mappiare-AT., A. 2010. Revitalisasi dan Pewarisan Nilai Budaya Unggul Nusantara Melalui Media Bimbingan dan Konseling. Prosiding Konferensi Nasional APPI. Universitas Negeri Malang, tgl. 16 - 17 Oktober: 132 147.

[13] Mappiare-AT., A. 2015. Konstruksi Karakter Berbasis Budaya Nusantara untuk Pendidikan dan Konseling Multibudaya Model KIPAS. Bimbingan dan Konseling, 28(2), 90-103.

[14] Mappiare-AT., A., Ibrahim, A.S. \& Sudjiono. 2009. Budaya Konsumsi Remaja-Pelajar di Tiga Kota Metropolitan Pantai Indonesia'. Jurnal Ilmu Pendidikan, 16(1), 12-21.

[15] Mappiare-AT., A., Fachrurrazy \& Sudjiono. 2010. Kecakapan Belanja Siswa, Kearifan Kultural, dan Media Bimbingannya. Jurnal Ilmu Pendidikan, 17(3), 178-188

[16] Mappiare-AT., A., Fachrurrazy \& Sudjiono. 2011. Pengembangan Media Bergambar Bimbingan Konseling untuk Pelatihan Keterampilan Komunikasi dan Soft-Skills. Jurnal Bimbingan dan Konseling, 24, Edisi April, 1-14

[17] Mappiare-AT., A., Fachrurrazy \& Sudjiono. 2012. Identifikasi Butir-Butir Budaya Unggul Nusantara sebagai Konten Media Bimbingan Karier Siswa. Bimbingan dan Konseling: Jurnal Teori dan Praktik, 25(25). 1 -6.

[18] Mappiare-AT., A., Fachrurrazy \& Faridati-Zen, E. 2014. Rumusan Sistematis Budaya Nusantara sebagai Konten Media Bimbingan dan Konseling Multibudaya. Ilmu Pendidikan: Jurnal Kajian Teori dan Praktik Kependidikan, 41(1), 15-24. 
[19] Mawadi, I. 2012. Pendidikan Life Skills Berbasis Budaya Nilai-nilai Islami dalam Pembelajaran. Nadwa: Jurnal Pendidikan Islam, 6(2): 215-230.

[20] Morris, B. 2014. The Impact of Culture \& Ethnicity on the Counseling Process: Perspectives of Genetic Counselors from Minority Ethnic Groups. Master's thesis. (Online) (http://scholarcommons.sc.edu/etd/2733), diakses 21 Januari, 2017.

[21] Prayitno. 1998. Konseling Pancawaskita. (Online). (http://labkonselingumk.blogspot.com/2012/09/konselingpancawaskita.html\#comment-form), diakses 23 Maret 2013.

[22] Riswanto, D., Mappiare-AT., A., dan Irtaji, M., 2017. Kompetensi Multikultural Konselor pada Kebudayaan Suku Dayak Kakimantan Tengah. JOMSIGN: Journal of Multicultural in Guidance and Counseling, 1(2), 215-226.

[23] Setyaputri, N.Y., Ramli, M. \& Mappiare-AT., A. 2015. Pengembangan Media Permainan "Roda Pelangi" untuk Meningkatkan Efikasi Diri (Self-Efficacy) Siswa SMP dalam Menghadapi Ujian. Bimbingan dan Konseling 28(1), $38-46$.

[24] Silondae, D. P. 2013. Model Bimbingan Kelompok Berbasis Budaya Suku Tolaki untuk Meningkatkan Keterampilan Sosial Siswa. Jurnal Bimbingan Konseling, 2(2), 64-70.

Dari http://journal.unnes.ac.id/sju/index.php/jubk,

[25] Simorangkir, M. 2014. Permainan Tradisional oleh Konselor Sekolah dalam Pembentukan Karakter Generasi
Muda. Prosiding: Guidance and Counseling International Seminar and Workshop, Juni: 394-397.

[26] Sugianto, A. 2017. Teknik Permainan Balogo dalam Layanan Bimbingan Kelompok untuk Meningkatkan Karakter Kerja Keras pada Siswa SMP. Proceeding Seminar dan Lokakarya Nasional Revitalisasi Laboratorium dan Jurnal Ilmiah dalam Implementasi Kurikukum Bimbingan dan Konseling Berbasis KKNI, Malang Jawa Timur, Agustus: 20-28.

[27] Sumari, M. \& Jalal, F. H., 2008. Cultural Issues in Counseling: An International Perspective, Counselling, Psychotherapy, and Health, 4 (1), Counseling in the Asia Pacific Rim: A Coming Together of Neighbors Special Issue, 24-34

[28] Suriata. 2015. Analisis Nilai-nilai Budaya Karia dan Implementasinya dalam Layanan Bimbingan dan Konseling. Jurnal Psikologi Pendidikan \& Konseling, 1(1): 9-18

[29] Widiasari, S., Susiati, I. \& Saputra, W.N.E. 2017. Play Therapy Berbasis Kearifan Lokal: Peluang Implementasi Teknik Konseling di Pendidikan Anak Usia Dini. Jurnal CARE (Children Advisory Research and Education), 04(1), 61-68.

[30] Yani, N. H. 2016. Bimbingan Kelompok dengan Permainan Tradisional untuk Meningkatkan Interaksi Sosial Peserta Didik di SD Muhammadiyah Pahandut Palangkaraya. Suluh: Jurnal Bimbingan Konseling, 2(2): 6-12. 